\title{
Potencial evocado auditivo de tronco encefálico como auxílio diagnóstico de morte encefálica ${ }^{* * * *}$
}

\author{
Brainstem auditory evoked potentials as a method to assist the \\ diagnosis of brain death
}

\author{
Mônica Jardim* \\ Osmar Clayton Person** \\ Priscila Bogar Rapoport***
}

*Fonoaudióloga. Mestre em Ciências da Saúde pela Faculdade de Medicina do ABC. Fonoaudióloga da Disciplina de Otorrinolaringologia da Faculdade de Medicina do ABC no Hospital Estadual Mario Covas de Santo André. Endereço para correspondência: R. das Aroeiras, 392 - apto 62 - Santo André - SP - CEP 09090-000 (m-jardim@ig.com.br)

**Médico Otorrinolaringologista. Mestre em Otorrinolaringologia pela Faculdade de Medicina de Ribeirão Preto da Universidade de São Paulo. Docente da Disciplina de Fonoaudiologia da Faculdade São Camilo.

***Médica. Doutora em

Otorrinolaringologia pela Faculdade de Medicina da Universidade de São Paulo. Professora Titular da Disciplina de Otorrinolaringologia da Faculdade de Medicina do ABC.

****Trabalho Realizado no Hospital Estadual Mario Covas.

Artigo Original de Pesquisa

Artigo Submetido a Avaliação por Pares

Conflito de Interesse: não

Recebido em 14.05.2007.

Revisado em 29.03.2008; 13.05.2008.

Aceito para Publicação em 13.05.2008.

\begin{abstract}
Background: brainstem auditory evoked potentials in brain death. Aim: to verify the agreement between the response in the auditory brainstem audiometry and the clinical outcome, analyzing the pattern of responses to electric stimulation. Method: a cross-sectional study performed in 30 patients with Glasgow coma score of 3 , submitted to the auditory brainstem audiometry and followed up until their clinical outcome: recovery or death. The test was considered positive to brain death when there was no registry of waves or when there was only the registry of wave I; and negative when there were two or more waves, independently of their latencies. Results: Among the patients who presented positive results for brain death $(86.66 \%)$, all died; the only patient who recovered presented a negative result, indicating a specificity of $100 \%$. Internal consistency of data was also observed, with an intraclass correlation coefficient of 0.562 , obtained using the Cronbach's test; and a significant agreement between the test and the clinical outcome using the Kappa's test, with a confidence interval of $95 \%(K=0.545 ; p=0.015)$. Conclusion: in the present study, the brainstem auditory evoked potential demonstrated to be highly specific in death prediction of patients in Glasgow coma score of 3, and was useful in assisting the diagnosis of brain death.
\end{abstract}

Key Words: Coma; Audiometry Evoked Response; Brain Death; Directed Tissue Donation.

\section{Resumo}

Tema: Potencial Evocado Auditivo de Tronco Encefálico aplicado em morte encefálica. Objetivo: verificar a concordância entre o resultado do Potencial Evocado Auditivo de Tronco Encefálico e o desfecho do quadro clínico, em pacientes em coma Glasgow 3, por meio da análise do padrão de resposta elétrica do teste. Método: estudo tipo transversal realizado em 30 pacientes em coma Glasgow 3 submetidos ao Potencial Evocado Auditivo de Tronco Encefálico e acompanhados quanto ao desfecho clínico após o teste: recuperação ou óbito. $\mathrm{O}$ teste seria considerado positivo para morte encefálica ao registrar com reprodutibilidade ausência de todas as ondas ou presença de apenas a onda I, e considerado negativo na presença de duas ou mais ondas independentes de suas latências. Resultados: entre os pacientes que apresentaram testes positivos para morte encefálica $(86,66 \%)$, todos foram a óbito e o único paciente que se recuperou apresentou teste negativo indicando especificidade de $100 \%$. Observou-se consistência interna dos dados, com coeficiente de correlação intraclasse de 0,562 por meio do Teste Alfa de Cronbach e concordância significativa entre o teste e o desfecho clínico por meio do Teste de Concordância de Kappa $(K=0,545 ; p=0,015)$, com intervalo de confiança de $95 \%$. Conclusão: para o presente estudo o Potencial Evocado Auditivo de Tronco encefálico demonstrou ser um teste altamente específico na predição de óbito em pacientes em coma Glasgow 3, e possibilitou auxiliar o diagnóstico de morte encefálica.

Palavras-Chave: Coma; Audiometria de Resposta Evocada; Morte Encefálica; Doação Dirigida de Tecido. 


\section{Introduction}

The coma is a state of unconsciousness without response to the environment caused by metabolic disorders, intoxication, systemic infections, intracranial lesions or psychic disorders (1). The degree of coma is commonly determined by the Glasgow scale, being that the score 3 in the scale corresponds to deep coma (2).

The recovery of the patient will depend on the cause and on the degree the coma, as well as on the localization and extension of the neurological damage. The irreversible coma is considered as brain death (BD) (1).

The necessity of creating criteria that defined $\mathrm{BD}$, was initiated on the Sixties, when the medical technological advance in relation to resuscitation techniques, extra corporal circulation and artificial breathing had allowed to keep the patient with the organs and systems working for an indeterminate period of time even in the case of total loss of the encephalic functions.

The necessity of obtaining the precocious diagnosis of BD for the procedures of organs transplant, objectifying to make possible the organs to be transplanted without deterioration or damages, is associated to the fact presented on the paragraph above (3-7).

The Conselho Federal de Medicina (Brazilian Federal Council of Medicine), in the resolution $n^{\circ}$. 1480 of 08/08/97, when defining the criteria for BD decided that: the clinical conclusion must necessarily be endorsed by subsidiary examination that demonstrates unequivocally absence of cerebral sanguineous perfusion, cerebral metabolic activity or cerebral electric activity.

The Brainstem Auditory Evoked Potential (BAEP) evaluates the electric activity of the ascending auditory pathway which resides all the way on the Brainstem (BS) segment responsible for the majority of the vital functions of the organism. The examination is simple, fast, objective, non invasive and it is not alternated with moderate hypothermia neither with high doses of barbiturates and other depressors of the central nervous system (9-11).

According to Hammer \& Crippen (12), the BS would be the indispensable central integrator unit for vital function of the organism. Therefore the clinical criterion for the BD diagnosis would consist of the demonstration of absence of electrical activity of the BS.

The use of BAEP in patients in coma as an instrument of the BS neurophysiological integrity gauging indicated trustworthy indices on the prediction of the coma prognostic and on the diagnosis of BD (13-17).

The present study has as objective to verify the relationship between the results of the BAEP and the outcomes of the clinical condition, in patients with score 3 in the Glasgow coma scale, by means of the analysis of the standard of electric response of the BAEP.

\section{Methods}

This research was approved by the Committee of Ethics in Research of the Medical School of ABC in $02 / 07 / 2003$ with protocol number $053 / 2003$. All the family members of the subjects had access to information referring to the research on the Consent Form, authorizing the inclusion of the subject in the research and the spreading of the results in agreement to the resolution 196/96 (18) on ethics in research with human beings.

A transversal study with 30 subjects in Glasgow 3 coma was carried through. The subjects were evaluated by the medical team in charge of the Intensive Care Unit of the State Hospital Mário Covas, in the city of Santo Andre. These subjects were submitted to the BAEP and followed up with regards to the outcome of the clinical condition, in the period between March, 2004 and March, 2006.

We analyzed the data of a total of 30 subjects, being that $19(63,33 \%)$ were male.

Of the 30 evaluated subjects, $20(66,66 \%)$ presented as cause of coma, intracranial injuries (cranial-encephalic trauma, encephalic vascular accident, cerebral tumor, and cerebral aneurysm) and $10(33,33 \%)$ presented as cause of coma metabolic, toxic and infectious alterations.

The age of the subjects ranged from 0,054 (20 days) to 92 years, being that $14(46,66 \%)$ of the subjects presented between 41 and 60 years. The relationship between age ranges and cause of coma are displayed in Table 1.

The used criteria for inclusion and exclusion of subjects are detailed below.

Inclusion criteria:

1. Clinical diagnosis of coma with score 3 , according to the Glasgow coma scale (2);

2. Normal Meatoscopy.

Exclusion criteria 
Damage of the auditory system as:

1.Hearing loss or other pathologies of the ear that could compromise the presence of the BAEP waves. Information obtained by means of questionnaire and/or previous examinations;

2. Fractures in temporal bone demonstrated by CAT scan registered in medical profile in subjects with history of cranial-encephalic trauma;

3. Infectious diseases of the central nervous system;

4. Demyelinated diseases, cerebral vascular accident of encephalic brainstem or tumors leased next to the auditory nerve or along the auditory pathway. Information obtained by means of questionnaire with family member and/or previous examinations;

5. Intracranial Hypertension;

6. Patients in hypothermia;

7. Device and background noise that exceed $30 \%$.

\section{Equipment}

The equipment used for the accomplishment of the BAEP was from Biologic Evoked Potential System Navigator®, model AUDX Plus, program EP 317 version 5.70, protocol AEP. The box of electrodes is composed by four electrodes of silver surface, being one active and two references. The abrasive paste for the exfoliation of derma was from Nuprep ${ }^{\circledR}$ and the electrodes were humidified with conducting paste from Ten 20 Conductive $®$, being settled by adhesive ribbon Micropore $®$. The used transducer was the earphone model TDH 39P by Telephonics®. The equipment were carried from the examination room to the Intensive Care Unit with an appropriate mobile table. The installation was made by unique electricity entrance with only one proper grounding and the use of voltage stabilizer and line filter.

\section{Procedures}

The subject selection was carried through by means of periodic visits into the adult and infantile Intensive Care Units of the hospital, verifying the existence of patients who presented score 3 in the scale of Glasgow evaluated by the responsible doctor and that met the inclusion criteria for the research.

After subject selection, the members of the family had access to the information referring to the research through the Consent Form and also before the accomplishment of the test, a questionnaire was applied to the family members with the objective to identify some exclusion criteria.

After the inspection of external acoustic meato, the derma where the electrodes were supposed to be placed was prepared with exfoliation with abrasive paste. Only after this procedure the electrodes were humidified with conducting paste, fixed and derivated in the following manner: an earth electrode derived in Fpz, one active in $\mathrm{Fz}$ and two of reference in $\mathrm{M} 1$ and $\mathrm{M} 2$ (composing two channels: Fz/M1 and Fz/M2) as the Norm IES 10/20 (International Electrode System) (19).

The impedance values of the electrodes were checked, having to be below than 5 Kohms. The acoustic stimulaton was presented as brief clicks of 100 milliseconds, in a rhythm of 13 stimulatons by second totaling 1024 stimulatons in a window of 10,24 milliseconds, polarity rarefied in the intensity of $90 \mathrm{~dB}$ NA, in both ears separately. Two registrations of each ear were carried through, with the purpose to evidence the presence of reproducibility of the waves and tracing overlapping. The used gain was 150000 with 3000 $\mathrm{Hz}$ high pass filters, low pass filter of $100 \mathrm{~Hz}$ and notch filter of $60 \mathrm{~Hz}$ activated.

For effect of analysis of the BAEP components, with the aim of the present study and based on significant literature data, the obtained results were divided into two groups:

\section{Positive test for BD:}

1. Absence of all the BAEP waves (absence of electric response of $\mathrm{BS}$ );

2. Or presence of only the wave I (component originated in peripheral portion of the cochlear nerve).

Necessary presence of one or another tracing bilaterally.

Negative test for BD:

1. Presence of at least two registered reproducible waves in BAEP such in normal as in abnormal latencies.

The researcher applied the test and the results were related to the clinical outcome. In order to verify the internal consistency of the data the intra class Alpha of Cronbach correlation coefficient was used and for the agreement analysis the test of Kappa, calculated through the average and standard deviation both with a confidence interval of $95 \%$. 


\section{Results}

In the present study $26(86,66 \%)$ positive and 4 negative tests for BD $(13,33 \%)$ were obtained. In relation to the total number of subjects, $29(96,66 \%)$ deceased and $1(3,33 \%)$ recovered. Amongst the positive results of the applied test, all subjects deceased. Amongst the negative results, $3(10 \%)$ deceased and $1(3,33 \%)$ recovered. With regards to the outcome of clinical profile, amongst the subjects that deceased, $26(86,66 \%)$ had presented positive test and $3(10 \%)$ had presented negative test. The only subject who recovered $(3,33 \%)$ presented negative test (Table 2). The relation of the results obtained in the test and the clinical outcome are demonstrated in figure 1.

The test presented sensitivity of $89 \%$, specificity of $100 \%$, positive predictive value of $100 \%$ and negative predictive value of $25 \%$, with accuracy of $90 \%$. The test also demonstrated positive veracity ratio of 0 and negative of 0,11 . Amongst the subjects who presented positive test for $\mathrm{BD}, 21(80,76 \%)$ presented absence of all the
BAEP waves and $5(19,23 \%)$ obtained presence of wave I, being that: $1(3,84 \%)$ presented unilateral wave I in normal latency, 2 (7,69\%) presented right wave I in normal latency and in increased latency the left, $1(3,84 \%)$ presented latency increased bilaterally and finally $1(3,84 \%)$ presented wave I in normal latency bilaterally.

With regards to the negative tests of $\mathrm{BD}, 4$ subjects $(13,33 \%)$ presented this result, being that 2 of them presented BAEP with waves III and V in increased latencies bilaterally and 1 subject presented latency of waves III and V increased in the right ear and absence of all the waves in the left ear. All of these subjects deceased. The subject whom presented negative test with presence of waves I, III and V in normal latencies recovered without sequels.

The Alpha Test of Cronbach, evidenced internal consistency, with intra class correlation coefficient of 0,562. Thorough the relationship Test of Kappa, it was observed that there was a significant agreement between the test and the clinical outcome $($ Kappa $=0,545 ; p=0,015)$, with confidence interval of $95 \%$.

TABLE 1. Relationship between cause of coma and age range.

\begin{tabular}{|c|c|c|c|c|c|c|}
\hline \multirow[t]{2}{*}{ Age range } & \multicolumn{2}{|c|}{$\begin{array}{l}\text { Metabolic, toxic and } \\
\text { infectious }\end{array}$} & \multicolumn{2}{|c|}{$\begin{array}{l}\text { Intracranial } \\
\text { lesions }\end{array}$} & \multicolumn{2}{|c|}{ Total } \\
\hline & & $\%$ & $\mathbf{N}^{\mathbf{o}}$ & $\%$ & $\mathbf{N}^{\mathbf{o}}$ & $\%$ \\
\hline 0 ------ 20 & 01 & 03,33 & 01 & 03,33 & 02 & 06,66 \\
\hline 21 ----- 40 & 01 & 03,33 & 07 & 23,33 & 08 & 26,66 \\
\hline 41 ----- 60 & 04 & 13,33 & 10 & 33,33 & 14 & 46,66 \\
\hline 61 ------ 80 & 03 & 10,00 & 02 & 06,66 & 05 & 16,66 \\
\hline ? $\quad$------ 81 & 01 & 03,33 & 00 & 00,00 & 01 & 03,33 \\
\hline Total & 10 & 33,32 & 20 & 66,65 & 30 & 99,97 \\
\hline
\end{tabular}

TABLE 2. Distribution of the number and percentage of subjects with regards to clinical outcome and result of BAEP.

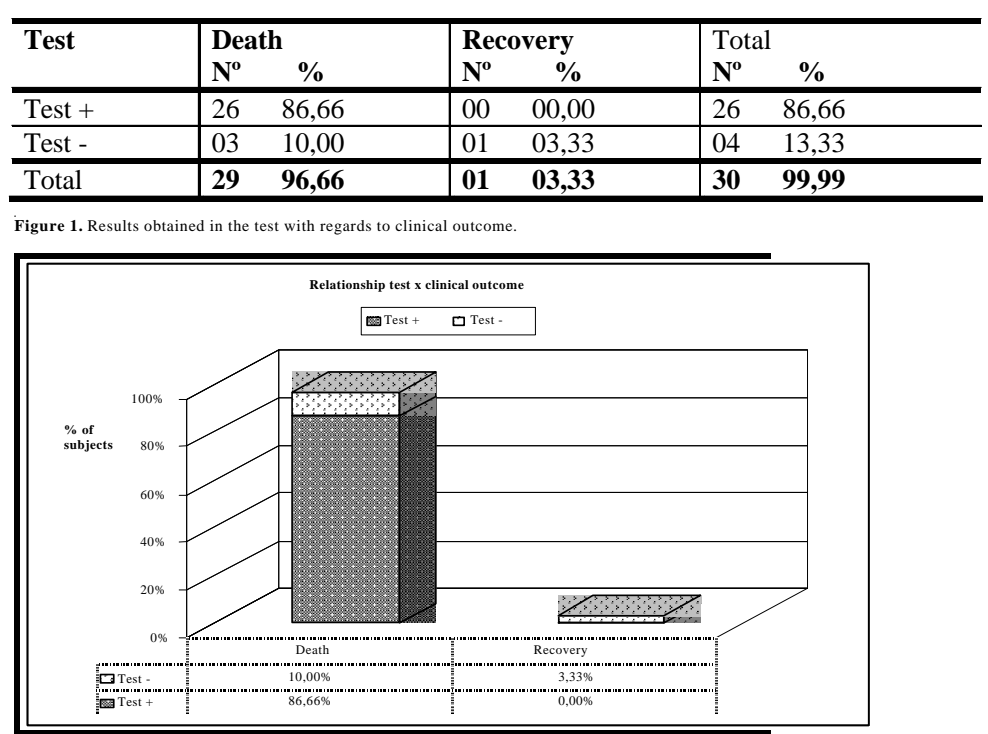




\section{Discussion}

The cerebral angiography, examination that evaluates the cerebral sanguineous perfusion, although it is considered a "gold standard" for the determination of $\mathrm{BD}$, is not carried through routinely due to inherent difficulties to the procedure and its high financial cost (17). On the other hand the EEG (electroencephalogram), examination that evaluates spontaneous cerebral electric activity of the cerebral hemispheres, is used for the determination BD. However the EEG suffers influences from potentially reversible conditions and some authors affirm to be a test of low specificity and that it should not be applied as the only examination for this intention (3).

Although the BAEP does not suffer alterations from depressive drugs of the central nervous system, in our casuistry there were not subjects users of these substances, highlighting that the Glasgow scale only applies to patients not in use of sedatives. We adopted as inclusion criteria for the study the presence of coma Glasgow 3, for being this the deepest period of coma and for best resemble the state $\mathrm{BD}$.

The obtained registers of the BAEP carried through in patients in deep coma on prior-terminal stage are stated with sufficient frequency by authors for presenting absence of all the waves or presence only of wave I (3-5-17). For this reason, in this study, the above findings were considered as a positive test for $\mathrm{BD}$ and the negative test corresponded to the presence of at least two waves.

Of the 30 subjects in Glasgow 3 coma that participated in the present study $29(96,66 \%)$ deceased and $1(3,33 \%)$ recovered. These data demonstrate that the subject in this stage of coma already has a predictive factor for death. Similar studies concluded that the association of the Glasgow scale to the BAEP determines indicatives on the prediction of the coma prognostic and on the diagnosis of BD (13).

Amongst the 29 subjects who deceased, 26 had presented positive test $(86,66 \%)$, data comparable to the obtained on similar studies carried through with children in Spain (90\%) (3). Amongst the subjects who deceased, three $(10 \%)$ had presented negative test, what implies false-negative tests, indicating sensitivity of $89 \%$ of the test. Of the positive tests of BAEP, all presented death as outcome, demonstrating improbability of falsepositives tests (positive predictive value of $100 \%$ ), as previous research had also demonstrated (17). The BAEP demonstrated to be a highly specific test $(100 \%)$ for the diagnosis BD, with accuracy of $90 \%$, and once more in agreement with studies on the subject (13-14-17).

If the monitorization for the BAEP was carried through in the subjects who had presented negative results for $\mathrm{BD}$ and had deceased, we believe that we would observe the accurate moment of the brainstem collapse, evidencing absence of electric response. Another important factor is the possibility to identify the absence of evoked response with eventual recovery, due to random factors of the BS injury (3-15-17).

In the present study, the only subject who has not deceased presented negative test with presence of waves I, III and V in normal latencies. The subject had awakened on the day following to the examination, recovering normally and being released from the Intensive Care Unite. The sedation was interrupted 24 hours before the accomplishment of the examination, moment when the subject was considered in coma Glasgow 3 according to clinical evaluation carried through by the medical team. The explanation can be based on the fact that the subject was obese and the sedative agents to presented greater predilection for adipose tissue (20). This would favor the maintenance of high concentrations of the agent in the sanguineous circulation for a greater period of time, sufficient to mask the clinical evaluation, however incapable to modify the responses of the BAEP.

When considering a simple, fast and highly specific test in the aid of the BD diagnosis we are also considering a new field for Audiology in a subject so important for the humanity.

Because of the fact that this is one of the most complex subjects of bioethics (6), we recognize that there is the necessity of the accomplishment of more research also involving continuous monitorization of BAEP, with improvement of the analysis and classification of tracings, adjusting them not only for the diagnosis of $\mathrm{BD}$ but also for the coma prognostic.

We believe that the BAEP will assist the medical team, in the majority of cases, to invest therapeutically in potentially recoverable patients, besides optimizing the programs of organ transplants in irretrievable patients. 


\section{Conclusion}

Within the presented casuistry, the BAEP presented significant relationship $(\mathrm{p}=0,015)$ with the clinical outcome. It demonstrated high specificity (100\%) in the prediction of death in patients in Glasgow 3 coma and, therefore, it makes possible to assist the diagnosis of brain death.

\section{References}

1. Monzillo PH, Gabbai AA, Luccas FJC. Coma. In: Knobel, E. Condutas no Paciente Grave $2^{\mathrm{a}}$ ed. São Paulo: Editora Atheneu; 1998. p. 697-716.

2. Teasdale G, Jennett B. Assessment of coma and impaired consciousness: a pratical scale. Crit. Care Med. 1997;2:81-4.

3. Ruiz-Loppez MJ, Azagra AM, Serrano A, Casado-Flores J. Brain Death and Evoked Potentials in Pediatric Patients (Pediatric Critical Care). Critical Care Medicine. 1999;27(2):412-6.

4. Manfro RC, Fernandes LNT. Morte encefálica e doação de órgãos. In: Barreto SSM, Vieira SRR, Pinheiro CTS. Rotinas em terapia intensiva. $3^{\mathrm{a}}$ ed. Porto Alegre; Artmed Editora, 2001. cap. 58. p. 535-42.

5. Oozgirgin ON, Ozaselik T, Sevimll NK. Auditory brain stem responses in the detection of brain death. Journal of ear, nose and throat. 2003;10:1-7.

6. Machado C, Korein J, Ferrer Y, Portela T, Garcia MI, Chinchilla M, Machado Y, Manero JM. The declaration of Sidney on human death. J Med Ethics. 2007;33:699-703.

7. Laureys S, Fins JJ. Are we equal in death? Avoiding diagnostic error in brain death. Neurology. 2008;70:14-5.

8. Resolução No 1480, 08/agosto/1997. Conselho Federal de Medicina. Publicado no Diário Oficial No 160,22/agosto/ 1997 - Seção 1-18227.

9. Misulis KE. PEATC anormais. In: Misulis KE. Potencial Evocados de Spehlmann. Potenciais Visual, Auditivo e Somatossensitivo Evocados no diagnóstico clinico. $2^{\mathrm{a}}$ ed. Rio de Janeiro; Revinter, 2003. cap. 13. p. 133-47.

10. Anias CR, Lima MAMT, Kós AOA. Avaliação da influência da idade no potencial evocado auditivo de tronco encefálico. Rev bras otorrinolaringol. 2004;70(1):84-9.

11. Person OC, Ruggieri-Marone M, Jardim M, Rapoport PB. A utilização dos potenciais evocados auditivos como método diagnóstico em medicina. Arq Med ABC. 2005;30(1):5-10.
12. Hammer MD, Crippen D. Brain death and withdrawal of support. Surg Clin North Am. 2006;86:1541-51.

13. Souza LCA, Piza MRT, Costa SS, Ferez M, Lavrador MAS, Kluwe LH. Associação do BERA ao escore de Glasgow (Índice GB): novo método de auxílio na decisão de predição de óbito em UTI. Rev Bras Terap Intens. 1998;10(4):15764.

14. Souza LCA. Contribuição dos Potenciais Evocados Auditivos de Tronco Encefálico (BERA) na Previsão de Óbito de Pacientes em Coma. 2003. 122 f. Tese de Doutorado defendida na faculdade de Medicina de Ribeirão Preto da Universidade de São Paulo.

15. Souza LCA, Piza MRT, Rodrigues LS, Ruiz DB, Schmidt VB. O BERA como instrumento de avaliação funcional do Tronco Cerebral em cirurgias com hipotermia profunda e parada circulatória total. Rev Bras Otorrinolaringol. 2003; 69(5):664-70.

16. Machado CSS, Barcelos WCO, Britto DBO, Manzi FR. Utilização do potencial evocado auditivo de tronco encefálico durante cirurgia de revascularização do miocárdio com circulação extra corpórea. Rev Soc Brás Fonoaudiol. 2006;11:284-9.

17. Sousa LCA, Colli BO, Piza MRT, Costa SS, Ferez M, Lavrador MAS. Auditory Brainsten Response: prognostic value in patients with a score of 3 on the Glasgow coma scale. Otology \& Neurotology. 2007;28:426-8.

18. Resolução no 196, 10/outubro/1996. Conselho Nacional de Saúde. Diretrizes e Normas Regulamentadoras de Pesquisa Envolvendo Seres Humanos.

19. Jasper, HH. The ten twenty electrode system of the international federation. Electroecephalography and Clinical Neurophysiology. 1958; 10: 371-5.

20. Charney DS, Mihic SJ, Harris, RA. Hipnóticos e sedativos. In: Goodman e Gilman. As bases farmacológicas terapêuticas. $10^{\circ}$ ed. Rio de Janeiro; Mc Graw-Hill, 2003. cap 17. p. 303-24. 
Pró-Fono Revista de Atualização Científica. 2008 abr-jun;20(2). 